\title{
EVALUATION OF FOREST FIRES IN PARANÁ IN 2018 AND 2019
}

\author{
Kendra Zamproni ${ }^{1^{*}}$, Heitor Renan Ferreira ${ }^{2}$, Antonio Carlos Batista ${ }^{3}$ \\ 1*Universidade Federal do Paraná, Programa de Pós-Graduação em Engenharia Florestal, Doutorado, Curitiba, Paraná, Brasil - \\ kendra.zam@gmail. \\ ${ }^{2}$ Universidade Federal do Paraná, Programa de Pós-Graduação em Engenharia Florestal, Doutorado, Curitiba, Paraná, Brasil - \\ bmheitorf@gmail.com \\ ${ }^{3}$ Universidade Federal do Paraná, Departamento de Ciências Florestais, Curitiba, Paraná, Brasil - batistaufpr@gmail.com
}

Received for publication: 29/06/2020 - Accepted for publication: 30/12/2020

\begin{abstract}
Resumo
Avaliação dos incêndios florestais ocorridos no Paraná nos anos de 2018 e 2019. Os incêndios florestais representam importantes prejuízos ambientais, econômicos e sociais em muitos países. O conhecimento histórico sobre as características dos incêndios ocorridos em certa região auxilia na tomada de decisão visando a prevenção e combate dos mesmos. O objetivo desta pesquisa foi avaliar os incêndios florestais ocorridos no estado do Paraná nos anos de 2018 e 2019, levantando as seguintes informações: município, região, mês e dia da semana da ocorrência e tipo de vegetação atingida. Para tanto, dados obtidos junto ao Corpo de Bombeiros do Paraná por meio da plataforma SysBMNew-CCB foram analisados, sendo verificada a densidade de incêndios por região e a análise comparativa entre conglomerados. Observou-se em 2019 um aumento de $42,25 \%$ no número de ocorrência de incêndios florestais em relação ao ano anterior. Para ambos os anos analisados, a região onde ocorreram mais incêndios florestais foi a Norte-central, seguida da região Metropolitana de Curitiba. O município que registrou maior número de ocorrências foi Curitiba, em ambos os anos. De acordo com a classificação do Corpo de Bombeiros, o tipo de vegetação mais atingido pelos incêndios, nos dois anos estudados, foi "terrenos baldios". A partir dos dados obtidos, verifica-se a necessidade de medidas de educação ambiental para a prevenção dos incêndios em terrenos baldios. É recomendado a continuidade deste estudo para que possa ser traçado um perfil dos incêndios florestais no estado, embasando medidas de prevenção e controle.

Palavras-chave: Caracterização; densidade de incêndios; fogo; interface urbano-rural; incêndios em vegetação.
\end{abstract}

\begin{abstract}
Forest fires represent significant environmental, economic, and social damage in many countries. Historical knowledge of their characteristics aids in making preventive decisions, as well as fighting forest fires. However, the general data of fires in Paraná are outdated. The objective of this study was to evaluate the forest fires in the state of Paraná in 2018 and 2019, surveying the following information: municipality and region affected; month and day of occurrence; and vegetation type. To this end, data obtained from the Paraná Fire Department through the SysBMNew-CCB platform were analyzed. The fire density by region was verified and compared through cluster analysis. Compared to the previous year, 2019 showed a $42.25 \%$ increase in the number of fires. In both years, most forest fires occurred in the North-central region, followed by the Metropolitan Region of Curitiba. The municipality of Curitiba recorded the highest number of fires in both years. According to the Fire Department classification, the vegetation type most affected by the fires was vacant lots. From the data obtained, we verified the need for environmental education measures aimed at the prevention of fires in vacant lots. Further research is recommended so that a profile of forest fires can be traced in the state and thus base prevention and control measures.

Keywords: Characterization; fire density; fire; wildland-urban interface, vegetation fires.
\end{abstract}

\section{INTRODUCTION}

Forest fires represent a major concern for many ecosystems (KUCUK et al., 2018), since they can cause imbalance and damage of economic, social, and environmental nature (BOWMAN et al., 2011). According to Rodríguez et al. (2013), the frequency of fires has increased in recent years on a global level, despite the available technologies and effort of governments and international organizations to fight them.

In view of this scenario, investing in actions to prevent and fight forest fires has become increasingly necessary. According to Torres et al. (2010), knowledge of the characteristics of fires is needed to enact policies on fire control, prevention, and management. For that end, statistics on the occurrence of fires in vegetation are the main tools, since the frequency of fires is a primary indicator to determine their characteristics (CHANG et al., 2015).

Time, place of occurrence, and quantitative distribution of fires throughout the year are variables that assist prevention planning, since they allow us to identify periods with higher risk of forest fires (RODRÍGUEZ et al., 2013). Assessment of which vegetation types are most susceptible to fire is also relevant, as ground for adopting specific management actions that may reduce the occurrence and effects of fires (SAMARA et al. 2018; TIAN et al. 2013). Particularly in the case of fires in urban areas and their interfaces, these data may lead to the 
formulation of guidelines toward more appropriate decision-making and planning. For Chas-Amil et al. (2013), anthropic activities occurring at urban-rural interfaces increase the likelihood of forest fires. In these interfaces, fires can have serious consequences for property and land use, in addition to posing a serious threat to life.

The development and implementation of effective prevention and control plans can only be achieved through analysis of accurate data on the characteristics of forest fires (VOSGERAU et al., 2006). Studies on the occurrence of fires need to be carried out continuously in order to create a consistent database that allows the prediction of fire hazard seasons. However, the latest data in published studies on fires in the State of Paraná is from 2011.

Within this context, the objective of this study was to characterize the forest fires that occurred in the state of Paraná in 2018 and 2019, in terms of region, time of occurrence, and vegetation types, in order to provide updated data for the fight and prevention of fires.

\section{MATERIAL AND METHODS}

\section{Characterization of the study area}

The state of Paraná, located in the southern region of Brazil, has a land area of 199,879.5032 km², which corresponds to $2.5 \%$ of Brazil (ITCG, 2019).

According to the database provided by Alvares et al. (2013) and to the Köppen classification, the predominant climates in the state are $\mathrm{Cfa}$ (humid subtropical) and $\mathrm{Cfb}$ (temperate oceanic), with the presence of Af (tropical rainforest), Am (tropical monsoon), and Aw (tropical savannah) in the northwest of the state (Figure 1A). The highest averages of annual rainfall in the state are concentrated in the East and Southwest regions (Figure 1B), whereas the highest averages of annual temperature are in the East and Northwest regions (Figure 1C).



Source: ITCG (2019), elaborated by the authors.

Figure 1. Climatic characterization of Paraná. A- Köppen classification, B- average annual precipitation, Caverage annual temperature.

Figura 1. Caracterização climática do Paraná. A - Tipos de climas que ocorrem no estado do Paraná segundo a classificação de Köppen, B - Precipitações pluviométricas médias anuais, C - Temperaturas médias anuais. 
Regarding vegetation, the state consists of different phytogeographic units: to the East, from the coastal plain to part of the Ribeira Valley, it is a dense Ombrophilous Forest; to the west of the Serra do Mar it is a mixed Ombrophilous Forest; in the North and West regions, it is a Semidecidual seasonal Forest. There are also remnants of steppe, interspersed with capons and gallery forests, usually located in the higher portions of the three plateaus of Paraná, and isolated areas of Savanna (Cerrado), located in the North and Northeast regions (RODERJAN et al., 2002).

\section{Database}

For the analysis of the forest fires that occurred during 2018-2019 in Paraná, the new database of the Fire Department of the Military Police of Paraná (SysBMNew-CCB) was used. The data analyzed from the records of the institution were:

- Municipality of occurrence;

- Month of occurrence;

- Day of the week of occurrence;

- Type of vegetation affected.

Only data from 2018 and 2019 were used due to the fact that, until 2017, the Fire Department adopted the category of "environmental fires" in its records, which covered both waste fires and forest fires. With the implementation of SysBMNew in 2017, the nature of the fire was added, in a division of "vegetation" and "others", which provides higher reliability in analyses of forest fire data.

A screening of the fire records was carried out in order to eliminate data that could represent dubious interpretations, such as the registration of the vegetation type as "garbage".

The municipalities were then grouped into geographical regions, according to The Division of Paraná's Institute of Economic and Social Development-IPARDES (IPARDES, 2012): Metropolitan area of Curitiba; Eastcentral; West-central; South-central; Southeast; Southwest; West; Northwest; North-central; North-pioneer; with the addition of the Coastal region (Figure 2).

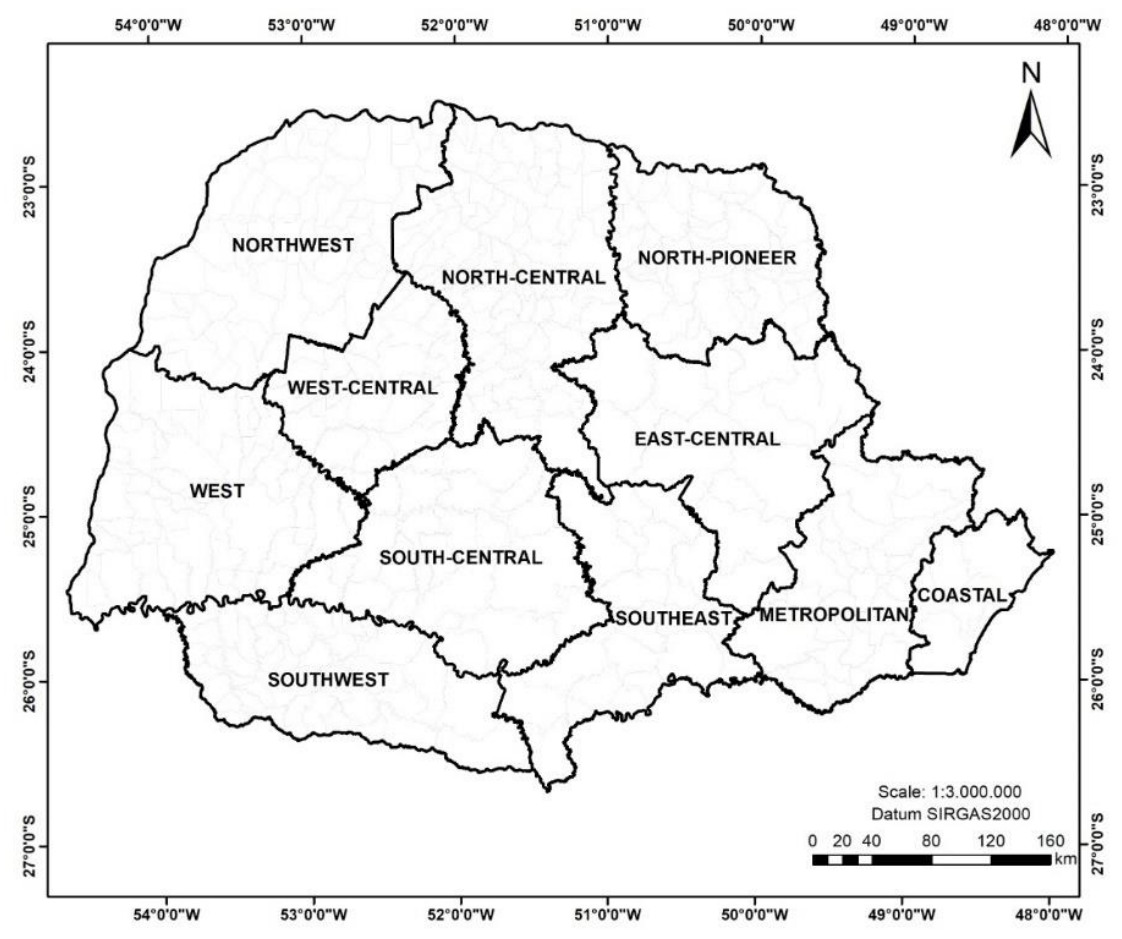

Source: IPARDES (2012), adapted by the authors.

Figure 2. Geographical regions of Paraná.

Figura 2. Regiões geográficas do Paraná.

An adaptation of the fire density (FD) index was used for the comparison between geographical regions: the number of records was divided per thousand hectares of total area of each geographical region, instead of per thousand hectares of vegetation cover of each geographical region. This adaptation was carried out because there are failures in the estimates of vegetated areas in urban centers, which result in an underestimation of park areas and vacant lots. 
The geographical regions were grouped with respect to FD by applying a cluster analysis following the Ward Method and the Euclidean squared distance.

The software used to run the maps was Arcgis Desktop (version 10.5). Excel (version 2016) and Statgraphics Centurion XVI (version 16.1.03) were used for the data analysis.

\section{RESULTS}

The amount of forest fires recorded in 2018 and 2019 in Paraná is shown in Figure 3. In 2018, 7,611 fires were recorded, distributed among 209 municipalities of 11 geographic regions. The North-central region presented the highest number of occurrences, with 1,962 forest fires (25.78\%). Regarding municipalities, Curitiba had the highest number of occurrences, 476 (6.25\%), followed by Maringá with 292 (3.84\%), and Ponta Grossa with 240 $(3.15 \%)$.

In 2019 , there were 10,827 forest fires in 258 municipalities, a $42.25 \%$ increase in the number of fires over the previous year. The North-central region had once again the highest number of fires, 2,438 occurrences $(22.52 \%)$. Curitiba also had once more the highest number of fires among cities, 501 (4.63\%), followed by Cascavel with 427 (3.94\%), and Ponta Grossa with 301 (2.78\%).



Figure 3. Number of forest fires in 2018-2019 by region in Paraná

Figura 3. Número de ocorrência de incêndios florestais nos anos de 2018 e 2019 por regiões no Paraná.

Comparing the two years, the Southwest had the largest increase in the number of fires among regions, with a $143.7 \%$ increase in 2019 , followed by the West, which showed an $80.4 \%$ increase.

Figure 4 shows the density of fires by region in the years analyzed and the cluster analysis among the geographic regions. Regions were grouped according to similarity, using fire density data. North-central showed the highest FD of all regions, with 0.8 (2018) and 1.0 (2019) fires for every thousand hectares of area, followed by the Metropolitan region of Curitiba, which had a FD of 0.7 and 1.0, respectively. 




Figure 4. Fire density by geographic region in 2018-2019 and cluster analysis.

Figura 4. Densidade de incêndios por região geográfica nos anos de 2018 e 2019 e análise de conglomerados.

The cluster analysis revealed three distinct groups of geographic regions in the state, by means of a fusion coefficient of 1.5. The North-central and Metropolitan regions presented the highest FD and were included in group 1. The Southwest, West, North-pioneer, Northwest, and East-central regions showed intermediate values and were included in group 2. Finally, the Coastal, Southeast, South-central, and East-central regions, which presented the lowest FD, were included in group 3.

Tables 1 and 2 show the monthly distribution of forest fires in 2018 and 2019 by geographic region. In 2018, July was the month with the highest concentration of fires.

Table 1. Fires by month and region in 2018.

Tabela 1. Ocorrências de incêndios ao longo dos meses no ano de 2018 nas diferentes regiões do Paraná.

\begin{tabular}{|c|c|c|c|c|c|c|c|c|c|c|c|c|}
\hline \multicolumn{13}{|c|}{2018} \\
\hline Region & JAN & FEB & MAR & APR & MAY & JUN & JUL & AUG & SEP & OCT & NOV & DEC \\
\hline North-central & 20 & 103 & 54 & 335 & 404 & 100 & 474 & 99 & 109 & 23 & 75 & 166 \\
\hline Metropolitan & 5 & 48 & 13 & 122 & 158 & 41 & 310 & 283 & 67 & 11 & 37 & 154 \\
\hline West & 19 & 76 & 35 & 111 & 140 & 21 & 109 & 90 & 55 & 24 & 36 & 121 \\
\hline Southwest & 9 & 49 & 33 & 148 & 154 & 35 & 182 & 60 & 38 & 9 & 26 & 68 \\
\hline Northwest & 11 & 31 & 18 & 79 & 147 & 67 & 215 & 33 & 52 & 10 & 35 & 53 \\
\hline North-pioneer & 4 & 11 & 9 & 90 & 82 & 14 & 139 & 91 & 67 & 9 & 36 & 75 \\
\hline East-central & 11 & 36 & 6 & 41 & 62 & 10 & 63 & 64 & 43 & 6 & 33 & 60 \\
\hline South-central & 5 & 8 & 8 & 44 & 32 & 9 & 103 & 54 & 37 & 4 & 29 & 48 \\
\hline Southeast & 5 & 16 & 0 & 28 & 25 & 1 & 38 & 46 & 17 & 0 & 16 & 76 \\
\hline West-central & 3 & 16 & 9 & 33 & 43 & 7 & 45 & 20 & 5 & 6 & 8 & 17 \\
\hline Coastal & 3 & 5 & 3 & 3 & 2 & 4 & 7 & 18 & 11 & 2 & 5 & 15 \\
\hline
\end{tabular}


In 2019, August showed the highest number of fires in most regions. Both in 2018 and 2019, the months with the highest number of fires (July and August) corresponded to winter, a season with historically lower rainfall levels and lower relative humidity in the state.

Table 2. Fires by month and region in 2019.

Tabela 2. Ocorrências de incêndios ao longo dos meses no ano de 2019 nas diferentes regiões do Paraná.

\begin{tabular}{lcccccccccccc}
\hline & \multicolumn{10}{c}{$\mathbf{1 0}$} \\
\hline Region & JAN & FEB & MAR & APR & MAY & JUN & JUL & AUG & SEP & OCT & NOV & DEC \\
\hline North-central & 101 & 194 & 76 & 211 & 90 & 194 & 317 & 616 & 296 & 246 & 77 & 20 \\
Metropolitan & 64 & 37 & 34 & 73 & 13 & 76 & 452 & 461 & 164 & 103 & 42 & 104 \\
West & 47 & 62 & 78 & 43 & 17 & 90 & 265 & 415 & 282 & 136 & 56 & 19 \\
Southwest & 35 & 29 & 56 & 30 & 6 & 41 & 178 & 286 & 217 & 129 & 22 & 31 \\
Northwest & 47 & 63 & 51 & 116 & 37 & 78 & 109 & 254 & 135 & 90 & 53 & 12 \\
North-pioneer & 44 & 50 & 50 & 69 & 45 & 68 & 114 & 224 & 119 & 127 & 40 & 23 \\
East-central & 29 & 21 & 32 & 37 & 10 & 42 & 244 & 251 & 67 & 61 & 39 & 19 \\
South-central & 10 & 4 & 34 & 9 & 3 & 17 & 190 & 132 & 82 & 31 & 11 & 6 \\
Southeast & 16 & 8 & 9 & 11 & 0 & 8 & 79 & 118 & 44 & 41 & 16 & 10 \\
West-central & 23 & 20 & 18 & 29 & 7 & 15 & 46 & 99 & 54 & 26 & 8 & 2 \\
Coastal & 12 & 6 & 1 & 8 & 0 & 7 & 7 & 6 & 2 & 16 & 4 & 21 \\
\hline
\end{tabular}

Relative fire frequencies by day of the week are shown in Table 3. The results varied among regions, but there was a slight concentration in the number of fires on Friday and Saturday.

Table 3. Distribution of the relative frequency of fires by day of the week and region in 2018 and 2019.

Tabela 3. Distribuição da frequência relativa de ocorrências de incêndios ao longo dos dias da semana para os anos de 2018 e 2019 por região no Paraná.

\begin{tabular}{|c|c|c|c|c|c|c|c|c|}
\hline \multirow{2}{*}{ Region } & \multirow{2}{*}{ YEAR } & \multicolumn{7}{|c|}{ DAY OF THE WEEK (\%) } \\
\hline & & SUN & MON & TUE & WED & THU & FRI & SAT \\
\hline \multirow{2}{*}{ North-central } & 2018 & 15.2 & 12.7 & 14.3 & 13.4 & 15.7 & 14.3 & 14.4 \\
\hline & 2019 & 17.7 & 13.5 & 12.6 & 12.6 & 12.9 & 12.8 & 18.0 \\
\hline \multirow{2}{*}{ Metropolitan } & 2018 & 16.5 & 13.4 & 13.3 & 8.9 & 13.9 & 16.9 & 17.1 \\
\hline & 2019 & 16.9 & 14.2 & 12.5 & 11.8 & 14.7 & 14.2 & 15.7 \\
\hline \multirow{2}{*}{ West } & 2018 & 13.4 & 13.5 & 15.4 & 14.2 & 15.4 & 13.1 & 14.9 \\
\hline & 2019 & 16.4 & 16.6 & 15.8 & 11.1 & 11.9 & 13.5 & 14.7 \\
\hline \multirow{2}{*}{ Northwest } & 2018 & 14.4 & 13.2 & 16.9 & 14.2 & 15.2 & 13.3 & 12.8 \\
\hline & 2019 & 15.3 & 12.5 & 14.4 & 12.9 & 13.3 & 14.4 & 17.2 \\
\hline \multirow{2}{*}{ North-pioneer } & 2018 & 16.5 & 16.6 & 13.6 & 9.6 & 13.6 & 13.4 & 16.6 \\
\hline & 2019 & 16.0 & 12.2 & 13.8 & 13.7 & 13.5 & 14.0 & 16.9 \\
\hline \multirow{2}{*}{ East-central } & 2018 & 13.6 & 14.0 & 14.5 & 13.1 & 12.8 & 16.1 & 15.9 \\
\hline & 2019 & 15.6 & 14.9 & 12.3 & 12.1 & 13.7 & 13.5 & 17.8 \\
\hline \multirow{2}{*}{ Southwest } & 2018 & 12.4 & 12.4 & 17.0 & 16.8 & 16.3 & 13.1 & 12.0 \\
\hline & 2019 & 15.8 & 17.8 & 12.9 & 13.7 & 13.1 & 11.1 & 15.6 \\
\hline \multirow{2}{*}{ South-central } & 2018 & 12.3 & 13.4 & 13.6 & 12.9 & 14.4 & 17.1 & 16.3 \\
\hline & 2019 & 19.1 & 15.9 & 11.2 & 14.0 & 13.8 & 11.7 & 14.4 \\
\hline \multirow{2}{*}{ Southeast } & 2018 & 14.6 & 17.2 & 11.6 & 10.1 & 13.1 & 20.1 & 13.4 \\
\hline & 2019 & 15.3 & 11.1 & 14.2 & 12.8 & 17.8 & 14.7 & 14.2 \\
\hline \multirow{2}{*}{ West-central } & 2018 & 13.7 & 12.7 & 17.0 & 11.8 & 12.7 & 17.9 & 14.2 \\
\hline & 2019 & 16.8 & 16.8 & 11.3 & 15.0 & 11.0 & 12.8 & 16.2 \\
\hline \multirow{2}{*}{ Coastal } & 2018 & 16.7 & 20.5 & 12.8 & 10.3 & 11.5 & 11.5 & 16.7 \\
\hline & 2019 & 6.7 & 18.9 & 10.0 & 14.4 & 15.6 & 13.3 & 21.1 \\
\hline
\end{tabular}


Table 4 shows affected vegetation types by region in 2018 and 2019.

Table 4. Affected vegetation types by region in 2018 and 2019, according to the Fire Department classification. Tabela 4. Tipo de vegetação atingida pelos incêndios nos anos de 2018 e 2019 por região no Paraná, de acordo com a classificação adotada pelo Corpo de Bombeiros.

\begin{tabular}{|c|c|c|c|c|c|c|c|c|c|c|c|}
\hline \multicolumn{12}{|c|}{2018} \\
\hline Vegetation/ REGION & NC & MC & $\mathbf{W}$ & $\mathbf{N}$ & NP & EC & SW & SC & SE & WC & $\mathbf{C}$ \\
\hline Grassland (native) & 80 & 161 & 20 & 19 & 39 & 99 & 23 & 28 & 16 & 11 & 6 \\
\hline Secondary vegetation & 264 & 280 & 336 & 74 & 115 & 156 & 174 & 115 & 73 & 31 & 12 \\
\hline Agriculture & 58 & 8 & 40 & 15 & 41 & 18 & 21 & 13 & 8 & 13 & 0 \\
\hline Mangrove & 3 & 3 & 3 & 1 & 0 & 0 & 0 & 1 & 0 & 0 & 0 \\
\hline Forest & 82 & 72 & 25 & 16 & 30 & 12 & 15 & 14 & 20 & 14 & 9 \\
\hline Pasture & 329 & 59 & 77 & 280 & 134 & 31 & 35 & 5 & 8 & 57 & 0 \\
\hline Forestation & 32 & 52 & 22 & 10 & 19 & 40 & 26 & 34 & 63 & 3 & 2 \\
\hline Restinga & 0 & 2 & 0 & 0 & 1 & 0 & 0 & 0 & 0 & 0 & 18 \\
\hline Vacant lot & 1114 & 612 & 314 & 396 & 372 & 271 & 141 & 171 & 80 & 83 & 31 \\
\hline \multicolumn{12}{|c|}{2019} \\
\hline Vegetation / REGION & NC & MC & $\mathbf{W}$ & $\mathbf{N}$ & NP & EC & SW & SC & SE & WC & $\mathbf{C}$ \\
\hline Grassland (native) & 114 & 248 & 76 & 30 & 39 & 159 & 39 & 30 & 22 & 22 & 13 \\
\hline Secondary vegetation & 311 & 423 & 584 & 100 & 145 & 228 & 436 & 168 & 110 & 77 & 11 \\
\hline Agriculture & 180 & 9 & 143 & 27 & 65 & 15 & 73 & 15 & 8 & 33 & 0 \\
\hline Mangrove & 1 & 15 & 3 & 3 & 2 & 0 & 0 & 2 & 1 & 0 & 1 \\
\hline Forest & 178 & 112 & 155 & 68 & 73 & 21 & 58 & 34 & 11 & 36 & 12 \\
\hline Unknown & 0 & 0 & 0 & 0 & 0 & 0 & 0 & 0 & 1 & 0 & 0 \\
\hline Pasture & 432 & 75 & 126 & 375 & 189 & 49 & 110 & 33 & 6 & 64 & 2 \\
\hline Forestation & 58 & 52 & 65 & 31 & 18 & 57 & 83 & 48 & 65 & 21 & 0 \\
\hline Restinga & 1 & 0 & 1 & 5 & 2 & 0 & 2 & 0 & 0 & 1 & 19 \\
\hline Vacant lot & 1163 & 689 & 357 & 406 & 440 & 323 & 259 & 199 & 136 & 93 & 32 \\
\hline
\end{tabular}

Legend: NC - North-central, MC - Metropolitan Curitiba, W - West, N - North, NP - North-pioneer, EC - East-central, SW - Southwest, SC South-central, SE - Southeast, WC - West-central, C - Coastal.

\section{DISCUSSION}

When analyzing forest fires in Paraná from 1991 to 2011, Vosgerau et al. (2006) found that a region comprising part of the North-central and the North-pioneer was the most affected by fires in that period, with $25.85 \%$ of the total of fire records. As for the municipalities, they found that Londrina had the highest number of fires with 3,552 occurrences (22.35\%), followed by Ponta Grossa with 2,339 (14.72\%), and Curitiba with 2,201 records (13.85\%).

In another study on forest fires in Paraná between 2005 and 2010, Tetto et al. (2012) observed that the Northwest region was more susceptible to fires, due to environmental factors such as climatic characteristics, vegetation cover, and the use of fire in agricultural practices. In the same study, they also verified that the coastal region was the least susceptible to fires, due to the region's higher average rainfall levels and specific vegetation type, which tends to inhibit fire initiation and spread. These findings corroborate the data found in our study.

Regarding months with a higher concentration of fires, our results are in line with what has been verified by other studies carried out in the state. Vosgerau et al. (2006) defined June to August as the fire hazard season since these months showed $53.18 \%$ of the fires in the analyzed period, especially August, with $24.47 \%$ of the records.

In the same sense, Tetto et al. (2012) also used the records of the Paraná Military Police's Fire Department and found that June to September was the fire hazard season, since this interval had $52.5 \%$ of the fires in the period they examined. In a study on forest fires in the municipality of Ponta Grossa-PR, Kovalsyki et al. (2014) pointed out that, from 2006 to 2013, July and August had the highest concentration of fires, with 36.3\% of the total records. Santos et al. (2019) also found that $47.52 \%$ of fires in the region of the city of Londrina happened from July to September. 
No day of the week had a significantly higher concentration of fires in our study, which corroborates the findings of Vosgerau et al. (2006) and Tetto et al. (2012).

The fact that most of the fires in this study occurred on vacant lots shows the importance of investing: in environmental education, so that the population learns not to handle these places with fire; in actions for a better use of these spaces; and also in inspection, in order to prevent fires and the damage they cause.

According to Ferreira et al. (2018), vegetation fires in urban areas and their interfaces are an environmental, social, and economic problem since they damage flora and fauna, directly or indirectly affect the population, and damage properties and other human resources. In addition, fires in urban areas may damage the local microclimate, affect air quality and the landscape, and also pose risks to the visibility of drivers.

Torres et al. (2010), in a study on vegetation fires in the urban area of Juiz de Fora-MG, found that $43.94 \%$ of occurrences happened in vacant lots throughout the city from 1995 to 2004 . The authors state that the amount of fires at these sites confirms their anthropic influence, since fire is used to clear these areas.

We recommend the continuation of this study for at least 3 more years, so that a profile of forest fires in Paraná can be traced with greater precision, and, thus, adequate prevention and control measures can be developed.

\section{CONCLUSION}

Based on our results, we concluded that:

- Vacant lots are the places most affected by forest fires in Paraná. The large number of fires in vacant lots is related to the common practice of clearing land with fire.

- To reduce the amount of fires in vacant lots, we recommend environmental education programs for the population and the adoption of effective prevention and inspection measures.

- In 2018 and 2019, the North-central region had the highest number of forest fires.

- In both years, the municipality with the highest number of fires was Curitiba.

- There was a 42.25\% increase in the number of fires from 2018 to 2019. Southwest and West regions had the highest percentage increases.

- The data obtained in this study follow the trend of other studies carried out in the state.

\section{ACKNOWLEDGMENTS}

The authors would like to thank the Academic Publishing Advisory Center (Centro de Assessoria de Publicação Acadêmica, CAPA - www.capa.ufpr.br) of the Federal University of Paraná (UFPR) for assistance with English language editing.

\section{REFERENCES}

ALVARES, C. A.; STAPE, J. L.; SENTElHAS, P. C.; GONÇALVES, J. L. M.; SPAROVEK, G. Köppen's climate classification map for Brazil. Meteorologische Zeitschrift, Stuttgart, v. 22, n. 6, p. 711 - 728, 2013.

BOWMAN, D. M. J. S.; BALCH, J.; ARTAXO, P.; BOND, W. J.; COCHRANE, M. A.; D’ANTONIO, C. M.; DEFRIES, R.; JOHNSTON, F. H.; KEELEY, J. E.; KRAWCHUK, M. A.; KULL, C. A.; MACK, M.; MORITZ, M. A.; PYNE, S.; ROOS, C. I.; SCOTT, A. C.; SODHI, N. S.; SWETNAM, T. W. The human dimension of fire regimes on Earth. Journal of Biogeography, [s. l.], v. 38, p. 2223 - 2236, 2011.

CHANG, Y.; ZHU, Z.; BU, R.; LI, Y.; HU, Y. Environmental controls on the characteristics of mean number of forest fires and mean forest area burned (1987-2007) in China. Forest Ecology and Management, Amsterdam, p. 563-565, 2015.

CHAS-AMIL, M. L.; J. TOUZA, J.; GARCÍA-MARTÍNEZ, E. Forest fires in the wildland-urban interface: A spatial analysisof forest fragmentation and human impacts. Applied Geography, [s. l.], n. 43, p. 127- 137, 2013.

INSTITUTO DE TERRAS, CARTOGRAFIA E GEOCIÊNCIAS - ITCG. Relatório de cálculo de área dos municípios do estado do Paraná - 2019 20 Disponível em: < http://www.itcg.pr.gov.br/arquivos/File/Dados_2019/RELATORIO_DE_CALCULO_DE_AREA_DOS_MUNI CIPIOS_DO_PARANA2019.pdf>. Acesso em: 20 mar. 2020.

INSTITUTO PARANAENSE DE DESENVOLVIMENTO ECONÔMICO - IPARDES. Relação dos municípios segundo as regiões geográficas do Paraná - 2012. Disponível em: < https://url.gratis/em0U5>. Acesso em: 18 jun. 2020.

FERREIRA, H. R.; BATISTA, A. C.; TETTO, A. F. Análise das ocorrências de incêndios em vegetação, no 
período de 2011 a 2015, no município de Curitiba, Paraná. In: RODRÍGUEZ, M. P. R.; GONZÁLEZ, A. J.; RODRÍGUEZ, R. G.; PONCE, S. I. C. (Org.). Investigaciones de pregrado sobre manejo del fuego. GuayaquilEquador: Grupo Compás, 2018, 178 p.

KOVALSYKI, B.; TETTO, A. F.; BATISTA, A. C.; SOUSA, N. J.; TAKASHINA, I. K. Avaliação da eficiência da Fórmula de Monte Alegre para o município de Ponta Grossa - PR. Enciclopédia Biosfera, Goiânia, v.10, n.19, p. 208-2018, 2014.

KUCUK, O.; BILGILI, E.; UZUMCU, R. Modeling surface fire rate of spread within a thinned Anatolian black pine stand in Turkey. Forest Systems, Madrid, v. 27, n. 2, 2018.

RODERJAN, C.V.; GALVAO, F.; KUNIYOSHI, Y. S.; HATSCHBACH, G.G. As unidades fitogeográficas do estado do Paraná, Brasil. Ciência \& Ambiente, Santa Maria, v. 24, p. 78-118, 2002.

RODRÍGUEZ, M. P. R.; SOARES, R. V.; BATISTA, A. C.; TETTO, A. F.; BECERRA, L. W. M. Comparação entre o perfil dos incêndios florestais de Monte Alegre, Brasil, e de Pinar del Río, Cuba. Floresta, Curitiba, v. 43, n. 2, p. $231-240,2013$.

SAMARA, T.; RAPTIS, D.; SPANOS, I. Fuel treatments and potential fire behavior in peri-urban forests in northern Greece. Environments, Basel, v. 5, n. 79, p. 1 - 13, 2018.

SANTOS, J. F. L. dos; TETTO, A. F.; BERTACCHI, A.; BATISTA, A. C.; SOARES, R. V. Comparison of forest fire profiles in Londrina, Brazil and Pisa, Italy. Floresta e Ambiente, Seropédica, v. 26, n. 2, 2019.

TETTO, A. F.; BATISTA, A. C.; SOARES, R. V. Ocorrência de incêndios florestais no estado do Paraná, no período de 2005 a 2010. Floresta, Curitiba, v. 42, n. 2, p. 391-398, 2012.

TIAN, X.; ZHAO, F.; SHU, L.; WANG, M. Distribuition characteristics and the influence factors of forest fires in China. Forest Ecology and Management, Amsterdam, v. 310, p. 460 - 467, 2013.

TORRES, F. T. P.; RIBEIRO, G. A.; MARTINS, S. V.; LIMA, G.S. Determinação do período mais propício às ocorrências de incêndios em vegetação na área urbana de Juiz de Fora, MG. Revista Árvore, Viçosa, v. 34, n. 2, p. 297-303, 2010.

VOSGERAU, J. L.; BATISTA, A. C.; SOARES, R. V.; GRODZKI, L. Avaliação dos registros de incêndios florestais do estado do Paraná no período de 1991 a 2001. Floresta, Curitiba, v. 36, n. 1, p. 23 - 32, 2006.

WARD, J. H. Jr. Hierarchical grouping to optimize an objective function. Journal of the American Statistical Association, [s.l.] v. 58, n. 301, p. 236-244, 1963. 